\title{
Socio-Cultural Determinants Affecting Political Participation And Satisfaction Of Women Councilors In Faisalabad
}

\author{
Sadia Nawaz \\ Department of Rural Sociology \\ University of Agriculture, Faisalabad \\ Ashfaq Ahmed Maann \\ University of Agriculture, Faisalabad \\ Muhammad Iqbal Zafar \\ University of Agriculture, Faisalabad
}

\begin{abstract}
Women encountered various challenges in political participation such as social, cultural, political and economic that hinder their empowerment. Women wellbeing are attained on social, economic and cultural grounds when they were politically empowered. This current study deals with the socio-cultural determinants and women councilors satisfaction via political involvement during session 2008-2010. The researcher employed the quantitative approach and selected 352 women councilors via systematic sampling technique from three different levels of councils in district Faisalabad. In this study, 83\% of the sample was drawn from union council, 8.5\% from the town/tehsil and district council. The data were analyzed through SPSS version 20. The findings revealed that most of the women were politically participated in different developmental activities and having a membership of monitoring committee. Most women representatives frequently responded to community problems. However, they encountered obstacles like lack of funds, non-payment of honorarium, salary problem, freedom of choice, mobility and health problems, lack of financial authority, educational attainment, decision making disengagement, separate washroom and waiting room. Bivariate analysis conducted between socioeconomic background of women councilors and political participation. Results indicated that women were more politically groomed and have political opportunities such as affiliation with political parties, having close relatives in politics and having knowledge about Local Government ordinance were more incorporated in political participation. In crux, higher education, professional training, provision of honorarium and freedom of decision making enhance women participation in political activities.
\end{abstract}

Keywords: Political Participation, Satisfaction, Women Councilors, Political Development.

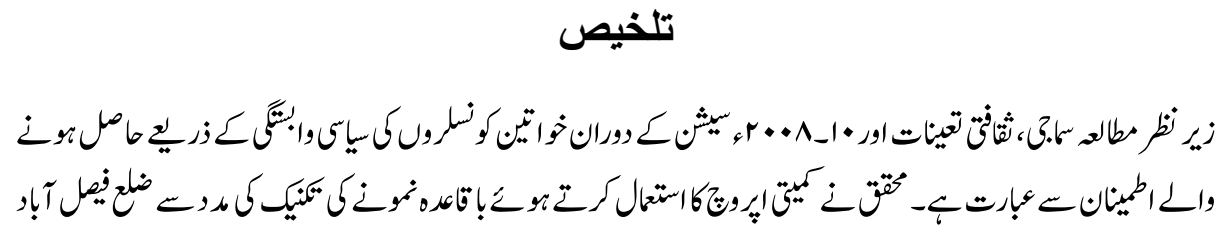




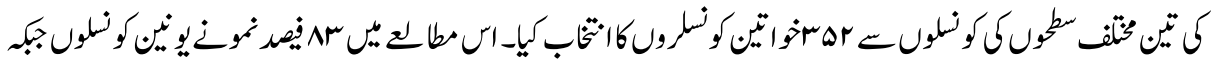

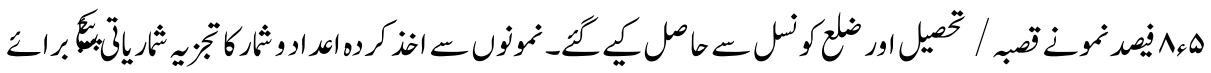

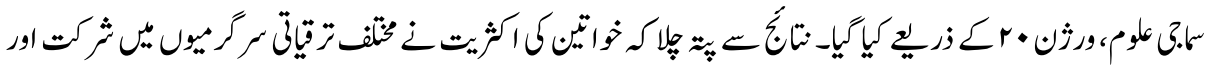

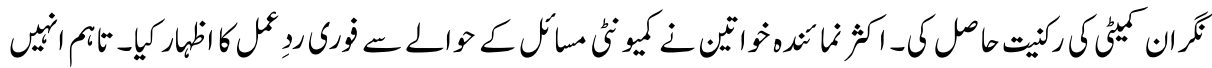

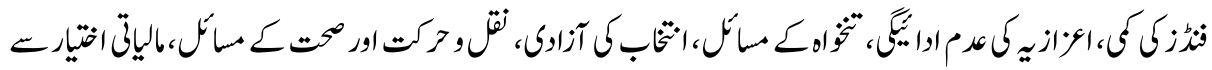

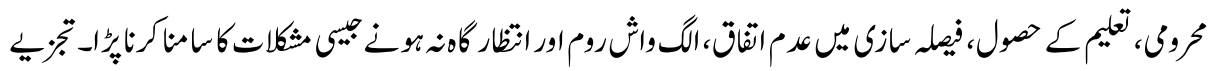

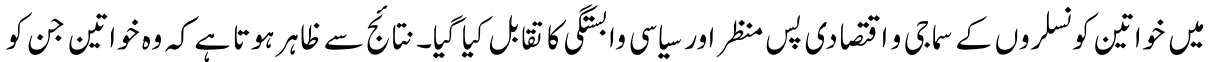

$$
\begin{aligned}
& \text { سياك. }
\end{aligned}
$$

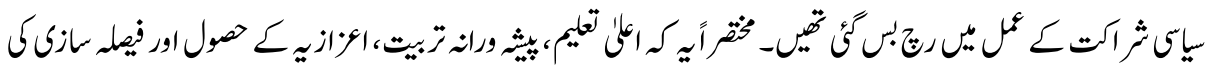

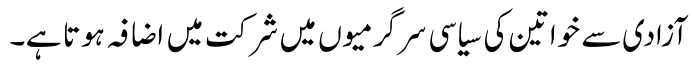

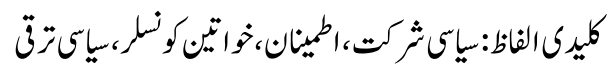

\section{Introduction}

Women are an integral part of society and make almost half of the globe. The pragmatic role of women has complemented the canvas of men's success almost in every field of life. All religions show high reverence to women but Islam gives more value to the position of females in a community. The law of Pakistan promises the same rights for both genders. Women status in Pakistan has improved somewhat (higher literacy rate of $47 \%$ in 2011-12 and lower unemployment rate of 1.18\% in 2010-11 (ECOSOC,2010; \& GoP, 2013); however, women still do not hold equal power to make decisions about their own lives, in their households, in the workplace and broader political issues of the country (Mahmood, 2002 \& Ali, 2010).

The social and political status of the women in Pakistan always is considered as a matter of discussion at domestic and international levels. It is a fact that women's status in Pakistani society is low by all social, economic and political benchmarks. Due to this place of women in society has become a subject of great concern. In the patriarchal system, men shape the political relationships of women. The subordinate position of women thwarts their participation in all areas of their lives is it in the home or in the public area. In the developed countries women's participation in politics is visibly apparent so is their progress and participation in those countries (Tariq, $2002 \&$ Repila, 2013).

Women can achieve politically empowered status when they set full representation on central and parliament level. Women are given liberty to take their decision regarding their personal matters then she is considered empowered. The traditional notion and 
patriarchal society hindered the women political participation at the local and global level (Sohail, 2014 \& Latif et al., 2015).

Cultural perceptions, social prejudices, and financial shortcomings are the key obstacles that impede the participation of women in politics. While taking an account of both the genders. Men were more active participants of parliamentary and political activities than women. It is also observed that domestic responsibilities hindered women political involvement. It was acknowledged that there are some economic, social, moral and political transformations which have gradually transmuted the patriarchal order of the Pakistani society. The precarious situation of Pakistani women in politics was alleviated to challenge the existing bottlenecks in politics in Pakistan (IPU, 2015; Kiev, 2011; Tahri, 2003; UNDP report, 2000 \& Latif et al., 2015).

National Commission on the status of women (2010) found that female participation in politics was minimal before the military government 2002 elections at three levels. PILDAT (2004) reported that women representation was increased to $33 \%$ at the local level under military rule 2000. In Pakistan National Assembly only 3\% seats are assigned to women ( 7 out of 217), In Senate, there are $2.3 \%$ seats for women ( 2 out of 87 ) and the overall ratio of a seat in the four provincial assemblies is ( 2 out of a total of 483). While in Punjab local bodies system, $12.5 \%$ seats are allotted to women, while in Baluchistan assembly the ratio is up to $27.6 \%$. Women in Pakistan are always been active in participating in politics as candidates, voters and political activist, in spite of this progress we are unable to produce a large number of female leaders of high caliber. The reason behind the fact is the male dominance and patriarchal uprightness in the political structure which hinders women's progress. Women in the political parties are not awarded a decisive status within the parties and are often not emerged as competitors during elections considering them devoid of political insight. The nature of political parties and the lifestyle of dissipation pervade in society. The fear of character termination effectively becomes a barrier in the participation of females (Latvia, 1995 \& Awan, 2016).

Khan (2009) identified that women quota enhanced in 2002 \& 2008 elections. Mode of election and women's presence in the parliament play a crucial role in politics. Indirect mode of election in Pakistan influenced the women's participation in the patriarchal scenario of Pakistani society.

National Commotion on the Status of Women (NCSW, 2009) proposed an idea, that in spite of joining the field of politics, women are not very independent and active in their activities and concerns. It is due to the fact that they are brought to the field of politics by men, but they are not given a proper environment to flourish as independent politicians as the patriarchal orders remain the same. The robust hegemonic rule, overwhelming influence, and strong patriarchal notions haven't lessened the female politician's precarious plight. The structures of inequality remain the same. This dilemma is the 
foremost hindrance to bring some transformation in the patriarchal culture of the Pakistani society (Shirkat Gah, 2009; Tabassum \& Afzal, 2015).

Parpart et al. (2003) argued that struggles to get chances for frequent participation in the field of politics, culture, and decision making the role of institutions is quite necessary for women empowerment. The women empowerment on an economic level is considered as a necessary factor for palpable development (betterment in education, sanitation, health problems) i.e. as it would enable the women to fight against the economic hurdles which may come during their journey of political participation.

A study deducted in remote areas of district Pishin and Mustang of Baluchistan province reported that the social and cultural values are considered as prominent obstacles for women's passive involvement in the activities related to their economic position. Those women that belong to the rural areas prefer their domestic earning activities which provide them small financial support for household as compared to out of a home-based income generating activities (Khan, 2000\& Bayeh, 2016). The current study aims to explore the councilor's socio-cultural determinants influence political participation. The researcher identifies threats and opportunities encountered in the way of political activity.

\section{Literature Review}

The main concern of this research study about the political empowerment of women. There are three levels of empowerment discussed at the intercultural level namely; the individual, the group and the conceptual. The first level of empowerment can be achieved through attaining skills by developing consciousness and by participating in networks or decisionmaking process. The second level of empowerment is at the local, national and global levels; where a group of people gains power through collective action. Finally, the third level of empowerment is called conceptual empowerment, which is considered as a process as well as the consequence of it. It includes power relations at all levels of society (Kabeer, 1999). A study conducted in rural areas of district Pishin and Mustang of Baluchistan province reported that the social and cultural factors are considered as major barriers for women passive participation in the financial activities. Women belonging to the rural areas prefer their domestic earning activities which provide them small financial support for household as compared to out of a home-based income generating activities (Khan, 2000).

A study conducted on women's involvement in politics reported that by facilitating female's active participation in politics and improving their position socially and economically, the state can increase their visibility in governance. This helps in achieving women rights and women's equality in society. Women's empowerment is quite necessary for improving all aspects of women's empowerment (Inayatullah, 1999; \& Girls, 2014). 


\section{Role of Women Councilors}

During the Pakistan movement, the leader of the Muslim nation, Quaid-e-Azam Muhammad Ali Jinnah encouraged women's prominent involvement in the freedom struggle. While addressing the processions on many occasions, he stated that the victimization of Muslims is not possible if they are involved in this struggle as same as men (Saiyid, 2006). Quaid-e-Azam; the father of the nation said that women should not confine themselves to the culturally assigned roles as a housewife (Samar, 2008). The military government of General Pervaiz Musharaf reserved 33\% quota for increasing involvement of women in politics at a provincial, domestic and national level. The purpose of reserving a quota of 33 percent is to establish equality on political grounds for women as guaranteed in the constitution. This generated interest among women at the grass root level.

\section{Political Participation of Women Councilors}

Women participation in politics aims to increase the number of females in politics, to enhance their effective participation in taking a decision. The national awareness campaign is framed by the government, NGOs, academics, researches, and agencies working for the social welfare of women and highlighted the vital role of women as role models at political, historical, artistic and scientific forums. Capacity building of women representatives should be initiated. The importance of capacity building can be judged from the fact reported by NRB (2004) that before the training programs started, the Nazims or the other male councilors used to say that women councilors could not contest. But the training program improved their understanding to a great extent and they began to perform their role in a better and effective manner. The capacity building of women councilors also includes teaching the rules and regulations and requirements outlined by the social safety net for extending financial assistance to poor people. The capacity building sessions should also involve women who are active in formal and informal political structure for incorporating their input and suggestions as there is no match for the personal experience (Drage, 2001).

The socio-cultural studies explored that various dimensions of participation of women in politics introduced, that such participation is generally asserted to be very overwhelming at the local level (Poland, 1997; Blair, 2008). In Bolivia, a law of equal participation came into practice in 1994 and in India under $73^{\text {rd }}$ and $74^{\text {th }}$ amendments in the constitution, exercise of authority at the local level organizations (Panchayats) were given more power and number of quota of $33 \%$ and resources were reserved for representation of women in this level of governance. In Pakistan too, the reservation of 33 percent quota in local self-government during 2000 proved a revolutionary step to ensure women's enrolment in politics at a local level. These local politics serves as the first training step for the women who want to be exposed to a vast public life (Esteva \& Parkash, 1997; Sachs, 1997). The studies while emphasizing the importance of females' role at the 
domestic level also directed that such politics also presents its own contest for women. Women are living in a village that is not a place of liberty or social security. In these villages, women experience culturally validated oppressions, exclusions, violations and surveillance at an extremely high level. Here most of the women population is living a miserable life and demands that democratic struggle should be organized to minimize the sufferings of the women (Stienstra, 2000; Liebowitz, 2002; Sawer, 2003; Staudt, 2003).

Dahlerup \& Freidenvall (2003) highlighted three arguments in accordance with women's participation on an equal level in formal politics; justice argument, the experience argument, and the interesting argument. The justice argument says that women are one of the two parts of the population and therefore deserve to be represented. The experience argument states that women's experiences differ from male experiences and should be involved in the discussion, dialogue, and debates for women-friendly policy-making and implementation. The last and third argument, interest argument, emphasized that the interests of males and females are quite different and this demands women reasonable representation in political institutions to articulate the interests of women.

\section{Research Methodology}

Quantitative approach and descriptive research design utilized, in addition, data was collected by self-administrated survey method. The universe of the study was limited to district Faisalabad of the Punjab province during session 2008-2010. A questionnaire with five points Likert scale utilized in this research. The multistage sampling technique used to locate the eligible respondents such as women councilors at three levels namely union council, town council, and district council. The total sample size comprised of 352 women councilors. In this study, $83 \%$ of the sample was drawn from union council, $8.5 \%$ from the town/tehsil council and $8.5 \%$ from the district council. At the third stage of the sampling, respondents were selected by employing a systematic random sampling technique. The questionnaire was distributed in all levels and dully filled and collected back. There was no missing data were located in question because the researcher administered this survey process. Data were analyzed using through SPSS version 20. Univariate data analysis showed in the tabulated form with frequency and percentage indication. Hypothesis testing is done with the help of a cross tab to check the effect of socioeconomic background on women's political participation.

\section{Results and Discussion}

This section elaborates the general description of socio-economic, cultural and political participation and empowerment of respondents (women councilors). Both Univariate and bivariate analysis incorporated in this section. In this analysis frequency distribution and percentages are presented to explain the different socioeconomic, demographic and political factors studied for this research. 
Table: 4.1

Socio-economic background of the women councilors

\begin{tabular}{|c|c|c|c|}
\hline Variable & Frequency(\%age) & Variable & Frequency (\%age) \\
\hline \multicolumn{2}{|c|}{ Area of residence } & \multicolumn{2}{|l|}{ Family Type } \\
\hline Urban & 187(53.1\%) & Nuclear & $188(53.4 \%)$ \\
\hline Rural & $165(46.9 \%)$ & Joint & $164(46.4 \%)$ \\
\hline \multicolumn{2}{|c|}{ Status of councilors' residence } & \multicolumn{2}{|c|}{ Marital status of the women councilors } \\
\hline Own house & $293(83.2 \%)$ & Married & $330(93.5 \%)$ \\
\hline Rented & $40(11.4 \%)$ & Widow & $22(6.5 \%)$ \\
\hline Free of cost & $19(5.4 \%)$ & \multicolumn{2}{|c|}{ Educational attaints of the women councilors } \\
\hline \multicolumn{2}{|c|}{$\begin{array}{l}\text { The current age of women } \\
\text { councilor at time of interview }\end{array}$} & Illiterate & $130(36.9 \%)$ \\
\hline Up to 34 & $37(10.5 \%)$ & Primary & $30(8.6 \%)$ \\
\hline $35-44$ & $109(31.1 \%)$ & Middle & $62(17.6 \%)$ \\
\hline 45-54 & $137(38.9 \%)$ & Matric \& Above & $130(36.9 \%)$ \\
\hline 55- and above & $69(19.6 \%)$ & $\begin{array}{l}\text { On which seat you were } \\
\text { elected? }\end{array}$ & Frequency \\
\hline \multicolumn{4}{|c|}{ On which seat you were elected? } \\
\hline General seats & $162(46 \%)$ & Minority seats & $21(6 \%)$ \\
\hline Reserved seats & $33(9.4 \%)$ & Special seat & $28(8 \%)$ \\
\hline $\begin{array}{l}\text { Peasant and } \\
\text { worker seats }\end{array}$ & $104(29.5 \%)$ & Town member & $4(1.1 \%)$ \\
\hline Total & $352(100)$ & & \\
\hline
\end{tabular}

The study shows that mainly (53.1\%) of the women councilors were living in urban areas, nuclear family system $(53.4 \%)$ and has their own houses $(83.1 \%)$. The study indicated that majority $38.9 \%$ women were in the $45-54$ years age group and $93.5 \%$ were enjoying the family life (married) while $6.5 \%$ were living without their husbands as either their husbands died or they were separated. This study revealed that $36.9 \%$ of women councilors were illiterate, while $17.6 \%$ got education up to primary level. Similarly, $17.6 \%$ got education up to middle level while $36.9 \%$ were either matric or above matric. This study narrated that majority of the respondents were illiterate due to lack of facilities. These illiterate women councilors may be elected at the union council level. The study revealed that slightly less than half $(46 \%)$ of the women councilors were elected on general seats, $9.4 \%$ on reserved seats, $29.55 \%$ on peasant and worker seats, $6 \%$ on minority seats, $8 \%$ on special seats and about $1.1 \%$ on town member seats.

Mosel and Jackson (2013) reported that Pakistan is amongst one of the top South Asian countries where the majority population living in urban areas for better facilities and can afford their own house due to government housing schemes (Alam, 2012). Khan et al. (2010) reported that a woman becomes empowered as she matures and it may be the reason that the majority of women councilors were aged. Pattan Development Organization (2001) \& Asifa (2006) reported that most women that entered in politics at 
the local government level belonged to low-income strata of the society. The recent study confirmed this finding.

Table: 4.2

Women close relative in politics, the attitude of male councilor/nazim, political background, and affiliation with political parties

\begin{tabular}{|c|c|c|c|}
\hline \multicolumn{2}{|c|}{ Close relative in politics } & \multicolumn{2}{|c|}{ Frequency(\%age) } \\
\hline i. & Yes & $123(34.9)$ & 34.9 \\
\hline & No & $229(65.1)$ & 65.1 \\
\hline \multicolumn{4}{|c|}{ If yes, explain the relation } \\
\hline i. & Family member & $21(17.7)$ & 17.07 \\
\hline ii. & Parents family & $77(62)$ & 62.60 \\
\hline iii. & In-laws family & $18(14.6)$ & 14.63 \\
\hline & Others (councilor) & $7(5.7)$ & 5.69 \\
\hline \multicolumn{4}{|c|}{ Politically affiliated with some party in the past? } \\
\hline i. & Yes & $136(38.6)$ & 38.6 \\
\hline ii. & No & $216(61.4)$ & 61.4 \\
\hline \multicolumn{4}{|c|}{ Would you like to contest the election in favor of that party? } \\
\hline i. & Yes & 136 & 38.6 \\
\hline ii. & No & 216 & 61.4 \\
\hline \multicolumn{4}{|c|}{ An attitude of male councilor/Nazim } \\
\hline i. & Democratic & 312 & 88.6 \\
\hline ii. & Authoritative & 40 & 11.4 \\
\hline \multicolumn{4}{|c|}{ Would you like to contest election again? } \\
\hline i. & Yes & 241 & 68.5 \\
\hline & No & 111 & 31.5 \\
\hline \multicolumn{4}{|c|}{ If yes, for which position } \\
\hline i. & Local Council & 138 & 57.26 \\
\hline ii. & District Council & 74 & 30.71 \\
\hline & Provincial Assembly & 20 & 8.30 \\
\hline & National Assembly/ Senate & 9 & 3.73 \\
\hline To & & 241 & 100.00 \\
\hline
\end{tabular}

The study approximately one third (35\%) have close relatives already active in politics while the majority $(65.1 \%)$ of them have no close relative in politics. Moreover, $17.07 \%$ of women councilors have their close relatives from the family while $62.60 \%$ from their parent's family. Only $14.63 \%$ of the women councilors have their in-laws family members in politics, while $5.69 \%$ of the women councilors have relative in politics. The study thus indicated that more than $60 \%$ of women councilors have close relatives from their parent family. In earlier studies, Bari (2001) and Yazdani (2003) also reported that the most women councilors who involved in the local government had full support and 
appreciation from their families who encouraged them to participate actively in politics through the local government system.

This study indicated that $38.6 \%$ women councilors were politically affiliated with political parties in the past and they agreed to contest election in favor of that party while $61.4 \%$ have no affiliation with any party in the past and they did not contest election in the favor of any party. Moreover, $68.5 \%$ of women councilors were ready to contest election again while $31.5 \%$ were not interested to contest election again. Among the women councilors who agreed to contest election again, $57.26 \%$ were willing to contest at local council level, $30.71 \%$ at the district level, $8.30 \%$ at the provincial assembly level and $3.73 \%$ at national assembly or Senate level.

Table: 4.4

Problems faced by women councilors while performing their duties

\begin{tabular}{|l|c|c|c|c|c|c|}
\hline Problems & \multicolumn{2}{|c|}{ Not at all } & \multicolumn{2}{c|}{ To some extent } & \multicolumn{2}{c|}{ To a great extent } \\
\hline & \multicolumn{2}{|c|}{ Frequency (\%) } & \multicolumn{2}{c|}{ Frequency (\%) } & \multicolumn{2}{c|}{ Frequency (\%) } \\
\hline Lack of funds & 47 & 13.3 & 47 & 3.3 & 258 & 73.3 \\
\hline Negative attitude of males & 157 & 44.6 & 111 & 31.5 & 84 & 23.9 \\
\hline Non-payment of honorarium & 78 & 22.2 & 85 & 24.1 & 189 & 53.7 \\
\hline Ineffective political role & 76 & 21.6 & 132 & 37.5 & 144 & 40.9 \\
\hline Salary problem & 25 & 7.1 & 86 & 24.4 & 241 & 68.5 \\
\hline Lack of proper guidance & 70 & 19.9 & 130 & 36.9 & 152 & 43.2 \\
\hline Separate washroom & 91 & 25.9 & 64 & 18.2 & 197 & 56.0 \\
\hline Separate waiting room & 105 & 29.8 & 50 & 14.2 & 197 & 56.0 \\
\hline
\end{tabular}

This study indicated that majority of women councilors $(73.3 \%)$ have faced problems of lack of funds to a great extent, while some women councilors $(3.35 \%)$ have faced this problem to some extent. However, $13.35 \%$ of women councilors have never faced the problem of a lack of funds during the performance of their duty. Likewise, $29.3 \%$ of women councilors reported that male attitude towards them was negative to a great extent, while $31.5 \%$ claimed that male attitude was negative to some extent. However, $44.6 \%$ said that male attitude was not negative. Moreover, the majority of women councilors $(53.7 \%)$ to a great extent claimed that honorarium was not paid to them, while $24.1 \%$ claimed about the nonpayment of honorarium. However, $22.2 \%$ said that honorarium was paid to them. This seems to be due to system inefficiencies or likes and dislikes which need to be corrected.

This study also deals with the ineffective political role that is faced by the women councilors in society. Our findings showed that $49.9 \%$ of women councilors faced this problem to a great extent, $37.5 \%$ to some extent, while $21.6 \%$ of women councilors have never faced this problem. Another problem faced by the women councilors in society is the salary for their services. They are paid so less that they feel dissatisfied with the amount received in return of the laborious and arduous efforts done for the public service. 
This is the problem due to which they do not perform their duties with full dedication and responsibility. Mostly women councilors $(68.5 \%)$ were facing a salary problem to a great extent, while $24.4 \%$ were facing this problem to some extent. Only a few women councilors $(7.1 \%)$ have never suffered the problem of payment of salary to them. Lack of proper guidance is also a problem for women councilors who faced these problems while performing their duties. A higher number of women councilors $(43.2 \%)$ were facing this problem to a great extent, while $36.9 \%$ were facing this problem to some extent, while $19.9 \%$ women councilors never faced this problem. Other problems faced by women councilors are the separate washroom and waiting room. Majority of the women councilors $(56 \%)$ claimed that they suffer the problem of the separate washroom to great extent, $18.2 \%$ suffered this problem to some extent, while $25.9 \%$ women councilors said that separate washroom was not a problem.

The majority $(56 \%)$ of women councilors argued that availability of separate waiting room was a problem for them to a great extent, $14.2 \%$ claimed that this was a problem to some extent, while $29.8 \%$ said that separate waiting room was not a problem. This study indicated that women councilors face a large number of problems viz. lack of funds, negative attitude of males, salary problems, ineffective political role and lack of proper guidance, separate washroom, and separate waiting room. These problems must be addressed by the concerned authorities to improve the working efficiency of the women councilors. Zulfiqar (2001) also suggested that women councilors were not given allowances across provinces while most of them belonged to the low-income group.

\section{Testing of Hypothesis}

The bi-variate analysis deals with the testing of the hypothesis. It explores the relationship between predicting and response variables through tables corresponding to each hypothesis. The nature and strength of the relationship is examined through the application of Pearson Chi-square, and gamma statistics.

Hypothesis 1: Political affiliation of the respondents with parties has an association with their satisfaction in politics as women councilors

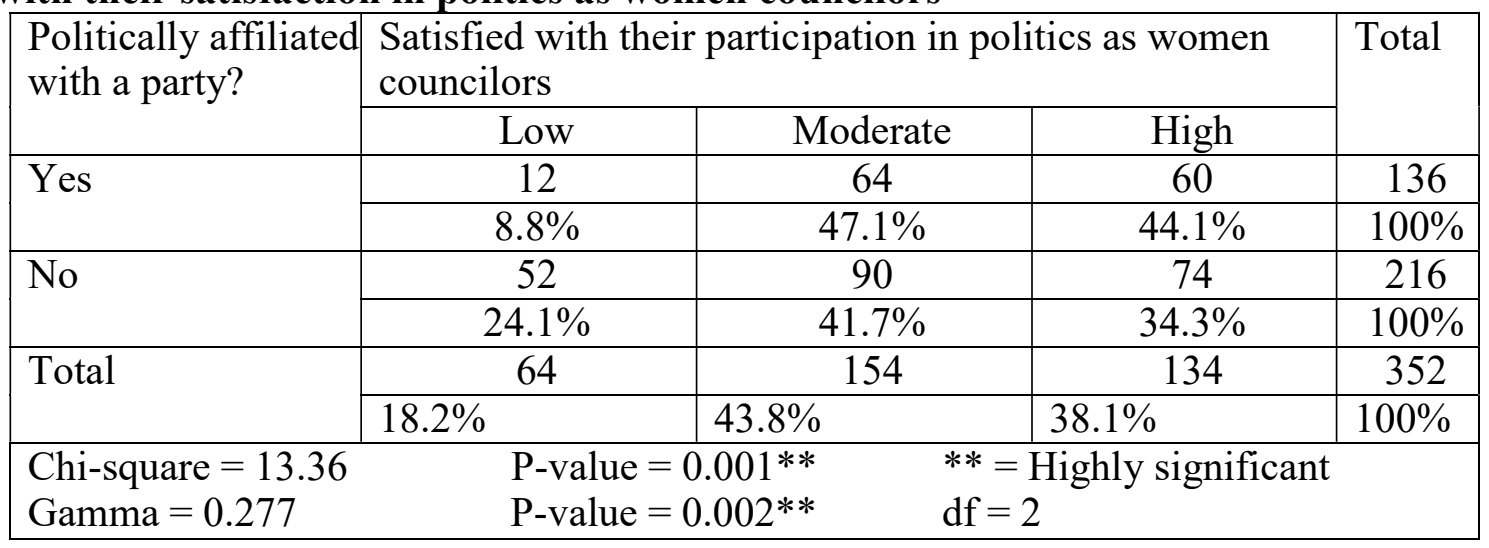


The relationship between political affiliation of women councilors with political parties and their satisfaction as women councilor. Chi-square value (13.36) shows a highly significant association between political affiliation of women councilors with political parties and their satisfaction as women councilor. The gamma value shows a positive and highly relationship between these variables.

Bennett, L. (2002) reported that women affiliated with an institution had good mental satisfaction than those having no affiliation. These findings confirmed that the affiliation of women with political parties was an essential element for empowering them. Furthermore, our findings of the study suggested that affiliation with political parties improve women to establish a network of social connection with the other members of that party.

Hypothesis 2: Higher the decision making the power of the respondents, more will be the satisfaction with participation in politics as women councilors

\begin{tabular}{|l|l|l|l|l|}
\hline \multirow{2}{*}{$\begin{array}{l}\text { Decision- } \\
\text { making power }\end{array}$} & \multicolumn{3}{|l|}{$\begin{array}{l}\text { Satisfied with their participation in politics } \\
\text { as women councilors }\end{array}$} & \multirow{2}{*}{ Total } \\
\cline { 2 - 5 } & Low & Moderate & High & \\
\hline \multirow{2}{*}{ Low } & 41 & 60 & 21 & 122 \\
\cline { 2 - 5 } & $33.6 \%$ & $49.2 \%$ & $17.2 \%$ & $100 \%$ \\
\hline \multirow{2}{*}{ Hedium } & 13 & 62 & 84 & 159 \\
\cline { 2 - 5 } & $8.2 \%$ & $39.0 \%$ & $52.8 \%$ & $100 \%$ \\
\hline \multirow{2}{*}{ Total } & 10 & 32 & 29 & 71 \\
\cline { 2 - 5 } & $14.1 \%$ & $45.1 \%$ & $40.8 \%$ & $100 \%$ \\
\hline \multirow{2}{*}{$\begin{array}{l}\text { Chi-square }=50.23 \\
\text { Gamma }=0.382\end{array}$} & 64 & 154 & 134 & 352 \\
\cline { 2 - 4 } & $18.2 \%$ & $43.8 \%$ & $38.1 \%$ & $100 \%$ \\
\hline
\end{tabular}

The results indicate that the power of decision making and their satisfaction as women councilor. Chi-square value (50.23) shows a significant association between the decisionmaking power of the respondents and their satisfaction as women councilor. The gamma value shows a highly significant positive relationship between these variables.

In our current party structure, women are not given chances to involve in the decisionmaking process within the group which lowers their satisfaction to participate in politics. In a study, the women councilors reported that they were given more respect by their families after their political participation and male family members started them to involve them in the decision-making process at a family which further increased their satisfaction with participation in politics as women councilor (Bari, 2009). Drage (2001) stressed that there was a need to adopt specific strategies to promote the involvement of women in decision making. 


\section{Conclusions}

Women being half of the world population cannot be secluded from the process in decision making for the development of their societies and nations. Now in the twentiethcentury women themselves are aware of their rights, are struggling hard to get equality for women in all walks of life. In spite of all the hurdles and obstacles women are gathering momentum and are raising voice for their rights.

Empowerment of women is directly involved in the participation of women in political activities because a powerful and trained woman is more capable of changing the fate of society. In Pakistan, the dream of democratic and harmonious society cannot flourish without the equal participation of women in the whole process of development. To achieve the proper status of women in society, it is very essential for Pakistani women to take an active part in political organization.

It was observed during the research that most of the women councilors included in the study sample were residing in urban areas, living in the joint family system, having low family size; moderate age, high education, satisfied with their monthly income, political participation and their political involvement in developmental activities. Similarly, women councilors having affiliation with political parties, having knowledge about LG ordinance and monitoring committee, having close relatives in politics and given more chances to speak, felt more satisfied with political participation and made more development through political involvement.

In crux, higher education, professional training, decision making in family matters increase women participation, satisfaction, and development in political involvement. Moreover, the respondents' husband education, the democratic attitude of male councilors, positively affected the participation of women councilors in politics. Providing incentives like payment of honorarium, daily allowance, training allowance, and transportation charges increase women's participation in politics related professional activities, their satisfaction, and development through political involvement.

\section{References}

Alam, L. (2012). Local Government Administration in Pakistan. Karachi, Unpublished Manuscript.

Ali, Hamidon (2010). Women's Empowerment and Gender Equality. Translating Words to Deeds: Achieving Gender Equality and Development To All. 
Awan, A.M. (2016). Political Participation of in Women in Pakistan Historical and Political Dynamics Shaping the Structure of Politics for Women, GoetheUniversitat, Frankfurt.

Asifa, H. (2006). Role of Civil Society Organizations in the Local Government Elections 2005, Pattan Development Organization, Islamabad.

Bari, F. (2009). Role and Performance Assessment of Pakistani Women Parliamentarians 2002-07, Pattan Development Organization, Islamabad.

Bari, F. (2001). Local Government Elections. Ministry of Women Development. pp.13-15.

Baltiwala, S. (1994). The Meaning of Women's Empowerment: New Concepts from Action. In: Sen, G.A., German and L.C. Chen (Eds.), Population Politics Reconsidered: Health, Empowerment, And Rights. Cambridge, Harvard University Press, pp.127-138.

Bayeh, E. (2016). The Role of Empowering Women and Achieving Gender Equality to the Sustainable Development of Ethiopia. Pacific Science Review B: Humanities And Social Science, vol.2:1, pp.37-42.

Bennett, L. (2002). Using Empowerment and Social Inclusion for Pro-Poor Growth: A Theory of Social Change. Working Draft of Background Paper for the Social Development Strategy Paper. Washington, DC. World Bank.

Bisnath, S. \& D. Elson. (1999). Women's Empowerment Revisited. Background Paper, Progress of the World's Women, UNIFEM. Available Online at: www.Unifem.Undp.Org/Progressww/Empower.Html (Accessed On January 09, 2008).

Blair, J. (2008). Equal Democracies? Gender and Politics in the Nordic Countries, Oslo University Press.

Dahlerup, D. \& L. Freidenvall. (2003). Quotas as a Fast Track to Equal Political Representation for Women. Paper Presented at the IPSA World Congress, Durban: South Africa, June 29 - July 4.

Drage, J. (2001). Women in Local Government in Asia and the Pacific: A Comparative Analysis of Thirteen Countries. Paper Presented to the Asia Pacific Summit of Women Mayors and Councilors Philsaulik, Thailand. 
ECOSOC (2010). Achieving Gender Equality, Women's Empowerment and Strengthening Development Cooperation, United Nation, New York.

Esteva, G. \& M.S. Prakash. (1997). From Global Thinking. In: Rahnema, M. and V. Bawtree (Eds.), The Post Development Reader London., Zed Books., Dhaka University Press Ltd., Halifax NS, Fern Wood Publishing And Cape Town: David Philip, pp.34-89.

GOP. (2013). Economic Survey of Pakistan 2012-13. Ministry of Finance, Government of Pakistan.

Inayatullah, A. (1999). A Historical Perspective on Women's Participation in Politics in Pakistan: Moving towards Change. Savera Publications.

IPU. (2015). Inter-Parliamentary Union, Women in Parliament: 20 Years in Review, Reuters/C. Jasso, 2014.

Kabeer, N. (1999). Reversed Realities: Gender Hierarchies In Development Thought. London: Verso.

Khan, A.R. (2000). Involvement of Rural Women in the Economic Activities of Baluchistan. J. Rural Devel. Adm. 31: 6-9.

Khan, A.(2009). Barriers to the Political Empowerment of Women in Dir Lower.

Khan, N.S. R. Saigol \& A.S. Zia. (2010). Locating the Self: Perspectives on Women and Multiple Identities. ASR Publication.

Latif, A., A. Usman \& J. Riaz. (2015). Female Political Participation in South Asia: A Case Study of Pakistan. South Asian Studies: Res. J. South Asian Studies, 30:201 $-213$.

Latvia, E. (1995). Reflection on the Conference on Women and Development. In: Harriet P. and G. Sen, (Eds.). Women's Empowerment and Demographic Processes: Moving beyond Cairo. New York: Oxford University Press, pp.320-342.

Liebowitz, D. (2002). Gendering (Tran) National Advocacy: Tracking the Lollapalooza at Home. Int. Feminist J. Pol. vol.4, pp.13-20.

Mahmood, N. (2002). Women's Role in Domestic Decision Making in Pakistan: Implications for Reproductive Behavior. Pak. Develop. Rev., vol.41, pp.121-148. 
Mosel, R. \& Jackson, P. (2013). Women Politicians: Transforming Westminster? Parliamentary Aff. 49:89-102.

NCSW. (2009). Extremism, Its Impact on Society: Implications for Women, National Commission on the Status of Women (NCSW).

National Commission on the Status of Women (2010). Gender Review of Political Framework for Women Political Participation. Review Report, Islamabad.

NRB. (2004). Report on the Orientation Workshops for Executive District Officers (Literacy).National Reconstruction Bureau, Islamabad.

Pattan Development Organization. (2001). Local Government Elections December, 2000 (Phase-1).

Parpart J.L., S.M. Rai \& K. Staudt. (2003). Rethinking Empowerment, Gender, and Development in A Local / Global World. London. Routledge, London.

Poland, A. (1997). Feminisms and Politics. Oxford University Press, Oxford.

PILDAT (2004). Women Representation in Pakistan's Parliament. Lahore Retrieved from: http://www.pildat.org.

Repila, J. (2013). The Politics of Our Lives: The Raising her Voice in Pakistan Experience. Oxfam. Retrieved from: https://www.Af.Org.Pk/Pub_Files/1396364563.Pdf

Sachs, W. (1997). The Need for the Home Perspective. In: Rahnema, M. and V. Bawtree (Eds.), the Post-Development Reader, Zed Books, Dhaka University Press, Dhaka, pp.222-267.

Saiyid, H. (2006). The Rhetoric of Difference. On Women's Inclusion into Political Elites. Pol. Soc. 2:1991-1996.

Samar, A. (2008). Quotas, Parity, and the Discursive Dangers of Difference. In: Maier, S.C. And J. Klausen (Eds.), Has Liberalism Failed Women? Assuring Equal Representation in Europe and the United States. New York Palgrave Press, New York, pp.311-356.

Sawer, M. (2003). The Life and Times of Women's Policy Machinery in Australia. In: Rai, S. (Ed.), Mainstreaming Gender, Democratizing The State? Institutional Mechanism for the Advancement of Women, Australia Publishing Press, Australia, pp.111-178. 
Sen, G. \& R. Grown. (1987). Scandinavian Feminist Debates on Citizenship. Int. Pol. Sci. Rev, vol.21, pp.345-360.

Sohail, M. (2014). Women Empowerment and Economic Development- An Exploratory Study in Pakistan. Journal of Business Studies Quarterly, vol.5:4, p.210.

Staudt, G. (2003). The Implementation of Gender Quotas in Peru: Legal Reform: Discourses and Impacts. Paper Presented at the Regional Workshop On "The Implementation of Quotas: Latin American Experience", IDEA, Lima: Peru.

Stienstra, D. (2000). Making Global Connection among Women: 1970-1999. In: Cohen, R. and S.M. Rai (Eds.), Global Social Movement, Rutledge, London, pp.219-267.

Tabassum, N.S; Tabassum, H; \& Tabassum, A. (2010). Women Representation in National Assembly of Pakistan. Grassroot, vol.49:1.

Tariq, H. (2002). Women Development in Pakistan. Third Australian Women and Policing Conference: Women and Policing Globally National Convention Centre, 20-23 October, Canberra, Australia.

UNDP, (2000). Women's Political Participation and Good Governance: $21^{\text {st }}$ Century Challenges, United Nations Development Program (UNDP).

Yazdani, F. (2003). Women Representation in Local Government in Pakistan: Impact Analysis \& Future Policy Implication, Islamabad, Pakistan.

Zulfiqar, M. (2001). Women and Economy: The Politics of Empowerment. Saarbrücken, Germany: Lambert Academic Publishing.

Sadia Nawaz is is Ph.D Scholar in the Department of Rural Sociology University of Agriculture Faisalabad.

Prof. Dr. Ashfaq Ahmed Maann is Dean Faculty of Social Sciences, University of Agriculture, Faisalabad.

Prof. Dr. Muhammad Iqbal Zafar is Pro. Vice Chancellor, University of Agriculture Faisalabad. 